Jurnal

Kardiologi Indonesia

J Kardiol Indones. 2014;35:80-6

ISSN $0126 / 3773$

Clinical Research

\title{
Association between Soluble Intercellular Adhesion Molecule- 1 and Soluble Vascular Cell Adhesion Molecule- 1 Levels and Left Atrial Thrombosis Gradation in Mitral Stenosis
}

\author{
Elen Sahara, Yoga Yuniadi, Ismoyo Sunu.
}

Department of Cardiology and Vascular Medicine, Faculty of Medicine, Universitas Indonesia,

and National Cardiovascular Center Harapan Kita, Jakarta
Background. The relationship between inflammation and coagulation has been widely described, which adhesion molecules play important role in inflammation. Soluble intercellular adhesion molecule-I (sICAM-I) and soluble vascular cell adhesion molecule-I (sVCAM-I) seem to be related to thrombosis in few previous studies. The level of those molecules were increased in mitral stenosis (MS), however their relationship with left atrial thrombosis gradation is still unknown.

Methods. Patients with moderate-severe MS (without any significant mitral regurgitation) who underwent transesophageal echocardiography were recruited consecutively in September-October 2013. They were divided into 3 categories of left atrial thrombosis gradation: non-thrombus without dense left atrial spontaneous echo contrast (LASEC) group, and non-thrombus with dense LASEC group, and thrombus group.

Results. A total of 39 subjects were enrolled in the study with a mean age of $40.97 \pm 9.6 \mathrm{I}$ year. Moreover, $7 \mathrm{I} .8 \%$ of them were female and $67.7 \%$ of them had atrial fibrillation (AF). Evaluation on left atrial thrombosis gradation as mentioned above showed that sICAM-I levels were 284.74 (2I8.79-32I.00) ng/mL, 346.86 (I 25.68-698.I2) ng/mL, and 395.93 (I7I.44$1021.53) \mathrm{ng} / \mathrm{mL}$, consecutively $(\mathrm{p}=0.280)$. While sVCAM- I levels gradually increased based on those groups consecutively: 729.0 I (543.93-967.80) $\mathrm{ng} / \mathrm{mL}, 1066.00$ (58I.36-2470.60) ng/mL, and I I 58.00 (668.66-2498.30) $\mathrm{ng} / \mathrm{mL}(\mathrm{p}=0.016)$. Multivariate analysis showed that $\mathrm{AF}$ and mitral valve area (MVA) influence thrombosis gradation.

Conclusion. Difference in sVCAM-I levels were found among left atrial thrombosis gradation groups in mitral stenosis, but its effect on thrombosis gradation was influenced by AF and MVA.

(J Kardiol Indones. 20 I4;35:80-6)

Keyword: adhesion molecule, thrombosis gradation, mitral stenosis 
Jurnal

\title{
Hubungan Kadar Soluble Intercellular Adhesion Molecule- 1 dan Soluble Vascular Cell Adhesion Molecule- 1 dengan Gradasi Trombosis Atrium Kiri pada Stenosis Mitral
}

\author{
Elen Sahara, Yoga Yuniadi, Ismoyo Sunu
}

\begin{abstract}
Latar belakang. Hubungan antara inflamasi dan koagulasi telah banyak dijelaskan, dimana molekul adhesi memiliki peranan penting dalam inflamasi. Soluble intercellular adhesion molecule-1 (sICAM-1) dan soluble vascular cell adhesion molecule-1 (sVCAM-1) tampak berkaitan dengan trombosis pada beberapa penelitian sebelumnya. Molekul-molekul tersebut meningkat pada stenosis mitral (SM) namun bagaimana hubungannya dengan derajat trombosis atrium kiri belum diketahui.

Metode. Pasien SM derajat sedang-berat (tanpa adanya regurgitasi mitral signifikan) yang menjalani pemeriksan ekokardiografi transesofageal diikutsertakan secara konsekutif sejak September-Oktober 2013. Penilaian gradasi trombosis atrium kiri dilakukan untuk mengkategorikan mereka menjadi kelompok non-trombus dengan left atrial spontaneous echo contrast (LASEC) tebal, dan kelompok non-trombus tanpa LASEC tebal, dan kelompok trombus. Kadar sICAM-1 dan sVCAM-1 dari vena perifer diukur dengan teknik enzyme-linked immunosorbent assay.

Hasil. Sebanyak 39 subyek penelitian dengan rerata usia 40,97 $\pm 9,61$ tahun, $71,8 \%$ berjenis kelamin perempuan, dan $67,7 \%$ memiliki irama fibrilasi atrium. Evaluasi terhadap gradasi trombosis atrium kiri sebagaimana disebutkan diatas menunjukkan kadar sICAM-1 sebesar 284,74 (218,79-321,00) ng/mL, 346,86 $(125,68-698,12) \mathrm{ng} / \mathrm{mL}$, dan 395,93 (171,44-1021,53) ng/mL secara berurutan ( $\mathrm{p}=0,280)$. Sedangkan kadar sVCAM-1 meningkat secara bertahap pada 3 kelompok tersebut: 729,01 $(543,93-967,80) \mathrm{ng} / \mathrm{mL}, 1066,00(581,36-2470,60) \mathrm{ng} / \mathrm{mL}$, dan $1158,00(668,66-2498,30) \mathrm{ng} / \mathrm{mL}(\mathrm{p}=0,016)$. Analisis multivariat menunjukkan fibrilasi atrium dan area katup mitral yang mempengaruhi gradasi trombosis.

Kesimpulan. Terdapat perbedaan kadar sVCAM-1 pada kelompok menurut gradasi trombosis atrium kiri pada SM, namun pengaruh sVCAM-1 terhadap gradasi trombosis atrium kiri dipengaruhi oleh fibrilasi atrium dan area katup mitral.
\end{abstract}

(J Kardiol Indones. 2014;35:80-6)

Kata kunci: adhesion molecule, gradasi trombosis, stenosis mitral

\section{Alamat Korespondensi}

Dr. dr. Yoga Yuniadi, SpJP, Departemen Kardiologi dan Kedokteran Vaskular FKUI, dan Pusat Jantung Nasional Harapan Kita, Jakarta. J. S Parman Kav 87, Jakarta I I420. E-mail: yogay I36@gmail.com

\section{Pendahuluan}

Stenosis katup mitral (SM) telah dikenali selama lebih dari 300 tahun sejak Vieussens mengemukakan tentang 
penyakit ini pada tahun 1705 . Pada saat ini prevalensi SM di negara-negara berkembang masih tinggi dan hal ini berkaitan erat dengan prevalensi demam reumatik. ${ }^{1,2} \mathrm{SM}$ merupakan faktor risiko terjadinya stroke, terutama pada pasien dengan fibrilasi atrium (atrial fibrillation$\mathrm{AF}$ ), left atrial spontaneous echo contrast (LASEC), usia $>40$ tahun, stenosis derajat berat, pembesaran atrium kiri, peningkatan hematokrit, dan penurunan curah jantung. Tromboembolisme pada pasien dengan SM mencapai $4 \%$ per tahun. Dalam upaya menjelaskan mekanisme dari kondisi pro-trombotik pada pasienpasien tersebut, studi-studi mengenai trombosis, sistem koagulasi, dan sistem fibrinolisis menemukan adanya abnormalitas hemostasis yang menunjukkan terdapatnya keadaan hiperkoagulabilitas pada SM. ${ }^{3,4}$

Goldsmith $\mathrm{dkk}^{5}$ menemukan bahwa penyakit katup mitral menyebabkan atrium kiri menyebabkan kerusakan endokardium. Mereka mengemukakan bahwa derajat kerusakan ini diasosiasikan dengan AF. Kerusakan tersebut berkontribusi terhadap risiko pembentukan trombus. Faktor lain yang terkait dengan pembentukan trombus di atrium kiri adalah aktivasi sistem koagulasi dalam atrium kiri. Pasien dengan SM memiliki kadar fibrinopeptida A, fragmen protrombin $1+2$, kompleks trombin-antitrombin III, D-dimer dan faktor Von Willebrand yang cukup tinggi pada atrium kiri. Penanda biokimia ini menunjukkan adanya pembentukan trombus bahkan selama terapi antikoagulan dan terlepas dari keparahan SM atau ukuran atrium kiri. Penemuan ini sesuai dengan studi sebelumnya yang menekankan pentingnya faktor-faktor lokal pada atrium kiri. ${ }^{4}$

Kaitan antara inflamasi dan trombosis memberikan penjelasan atas temuan klinis bahwa beberapa pasien AF yang mengalami kejadian trombosis walaupun telah mendapat terapi antikoagulan. Pasien-pasien tersebut ternyata memiliki kadar $C$-reactive protein (CRP) yang signifikan lebih tinggi dibandingkan dengan pasien tanpa trombosis. ${ }^{6}$ Intercellular adhesion molecule-1 (ICAM-1) dan vascular cell adhesion molecule-1 (VCAM-1) merupakan sel glikoprotein permukaan yang diekspresikan pada sel endotel yang memiliki peranan penting dalam respon imun dan inflamasi. Molekul adhesi yang bersirkulasi, seperti soluble intercellular adhesion molecule-1 (sVCAM-1) dan soluble vascular cell adhesion molecule-1 (sVCAM-1), telah terbukti meningkat pada pasien dengan SM. ${ }^{7}$ Beberapa penelitian telah memaparkan asosiasi ICAM-1 dan VCAM-1 dengan proses dan kejadian trombosis ${ }^{8-10}$, namun belum pernah diteliti hubungan ICAM-1 dan VCAM-1 dengan trombosis atrium kiri pada SM. Pada penelitian ini akan dicari adakah hubungan antara kadar molekul adhesi (sICAM-1 dan sVCAM-1) dengan gradasi trombosis di atrium kiri yang dinilai dengan ada/tidaknya trombus dan gradasi LASEC.

\section{Metodologi}

\section{Subyek Penelitian}

Desain penelitian ini adalah studi potong lintang. Sampel penelitian diambil secara konsekutif. Penelitian dilakukan di Departemen Kardiologi dan Kedokteran Vaskular Fakultas Kedokteran Universitas Indonesia/ Pusat Jantung Nasional Harapan Kita Jakarta, mulai September 2013 sampai Oktober 2013. Subyek penelitian adalah pasien dengan SM yang menjalani pemeriksaan ekokardiografi transtorakal dan transesofageal di Pusat Jantung Nasional Harapan Kita, Jakarta. Kriteria inklusi meliputi kasus SM signifikan (MVA $\leq 1,5 \mathrm{~cm}^{2}, \mathrm{mMVG} \leq 6 \mathrm{mmHg}$ ). Kriteria eksklusi meliputi adanya regurgitasi mitral signifikan (diatas derajat ringan), terdapat riwayat diabetes mellitus, hipertensi, keganasan, penyakit inflamasi, penyakit vaskular kolagen, trombosis vena dalam, emboli paru, demam reumatik akut dalam 6 bulan terakhir, atau operasi 3 bulan terakhir.

\section{Penilaian gradasi trombosis}

Pemeriksaan ekokardiografi transtorakal dan transesofageal dilakukan untuk menilai ada/tidaknya trombus dan gradasi LASEC dengan mesin ekokardiografi Phillips IE-33. Pada pasien yang mendapat terapi warfarin, warfarin distop 3 hari sebelum pemeriksaan ekokardiografi. Pengelompokan subyek penelitian menjadi kelompok trombus, kelompok non-trombus dengan LASEC tebal, dan kelompok non-trombus tanpa LASEC tebal. Trombus atrium kiri didefinisikan sebagai massa yang melekat pada dinding atrium kiri dengan ekodensitas yang berbeda sedangkan LASEC didefinisikan sebagai gema dinamik yang menyerupai asap dengan gerakan berputar di atrium kiri. LASEC dinilai melalui ekokardiografi transesofageal dengan gradasi yang dibedakan berdasarkan ada/tidaknya LASEC yang tebal/tampak pada seluruh atrium kiri. Penilaian gradasi trombosis dilakukan oleh 3 orang pengamat dan dinilai variabilitas interobserver dan intraobserver. Perbedaan interpretasi ditentukan dengan konsensus 


\section{Pengukuran kadar sICAM-I dan sVCAM-I}

Pengambilan darah untuk pemeriksaan sICAM-1 dan sVCAM-1 dilakukan dalam rentang 24 jam dari pemeriksaan ekokardiografi. Sampel darah sebanyak $5 \mathrm{~mL}$ diambil dari vena perifer dan dimasukkan ke dalam tabung yang mengandung $K 3$ ethylenediamine tetra-acetic acid. Sampel darah disentrifugasi untuk memisahkan serum. Kemudian serum disimpan pada suhu $-80^{\circ} \mathrm{C}$. Selanjutnya pemeriksaan kadar sICAM-1 dan sVCAM-1 dilakukan secara bersamaan pada seluruh sampel dengan teknik enzyme-linked immunosorbent assay (ELISA) dengan peralatan dari R\&D Systems, Abingdon, United Kingdom.

\section{Analisis statistik}

Penyajian data dengan mean \pm SD atau median (minimal-maksimal) untuk data kontinyu dan proporsi untuk data kategorik. Dilakukan uji Anova atau uji Kruskal-Wallis. Batas kemaknaan $\mathrm{p}<0,05$. Analisis multivariat dilakukan dengan uji regresi logistik multinomial.

\section{Hasil Penelitian}

Total subyek pada penelitian ini sebanyak 39 kasus dengan usia sekitar 40 tahun dan sebagian besar perempuan. Irama jantung pada sebagian subyek penelitian berupa AF. Karakteristik dasar masingmasing kelompok tersebut ditampilkan pada Tabel 1.

Subyek penelitian ini dibagi menjadi 3 kelompok menurut gradasi trombosis yaitu: kelompok nontrombus tanpa LASEC tebal sebanyak 15,4\%, kelompok non-trombus dengan LASEC tebal sebanyak $35,9 \%$, dan kelompok trombus sebanyak $48,7 \%$. Rerata kadar sICAM-1 tertinggi didapatkan pada kelompok trombus yang kemudian diikuti kelompok non-trombus dengan LASEC tebal dan kelompok nontrombus tanpa LASEC tebal secara berurutan, namun

Tabel 1. Karakteristik dasar penelitian $(\mathrm{n}=39)$

\begin{tabular}{ll}
\hline Variabel & Nilai \\
\hline Usia (tahun) & $40,97 \pm 9,61$ \\
Jenis kelamin-perempuan & $71,8 \%$ \\
BMI & $20,43 \pm 3,11$ \\
AF & $26(67,7 \%)$ \\
MVA $\left(\mathrm{cm}^{2}\right)$ & $0,6(0,3-1,5)$ \\
mMVG $(\mathrm{mmHg})$ & $12(4-26)$ \\
LAd $(\mathrm{mm})$ & $50,89 \pm 7,36$ \\
LAVi $\left(\mathrm{mL} / \mathrm{m}^{2}\right)$ & $90(33-209)$ \\
INR & $1,14(0,92-1,64)$ \\
\hline
\end{tabular}

$\mathrm{BMI}=$ body mass index, $\mathrm{AF}=$ atrial fibrillation $\mathrm{MVA}=$ mitral valve area $; \mathrm{mMVG}=$ mean mitral valve gradient LAd = left atrial dimension; $\mathrm{LAVi}=$ left atrial volume index

Tabel 2. Analisis bivariat terhadap gradasi trombosis atrium kiri

\begin{tabular}{|c|c|c|c|c|}
\hline Variabel & $\begin{array}{l}\text { Non-trombus tanpa LASEC tebal } \\
\qquad(\mathrm{n}=6)\end{array}$ & $\begin{array}{l}\text { Non-trombus dengan LASEC tebal } \\
\qquad(\mathrm{n}=14)\end{array}$ & $\begin{array}{c}\text { Trombus } \\
(\mathrm{n}=19)\end{array}$ & $\mathrm{p}$ \\
\hline Usia (tahun) & $41,67 \pm 16,52$ & $39,64 \pm 7,56$ & $41,74 \pm 8,69$ & 0,827 \\
\hline Jenis kelamin & & & & $0,032^{*}$ \\
\hline Laki-laki & $1(16,7 \%)$ & $1(7,1 \%)$ & $9(47,4 \%)$ & \\
\hline Perempuan & $5(83,3 \%)$ & $13(92,9 \%)$ & $10(52,6 \%)$ & \\
\hline Irama jantung & & & & $<0,001^{*}$ \\
\hline Sinus ritme & $5(83,3 \%)$ & $7(50 \%)$ & $1(5,3 \%)$ & \\
\hline $\mathrm{AF}$ & $1(16,7 \%)$ & $7(50 \%)$ & $18(94,7 \%)$ & \\
\hline $\operatorname{MVA}\left(\mathrm{cm}^{2}\right)$ & $1,04 \pm 0,42$ & $0,7 \pm 0,18$ & $0,55 \pm 0,18$ & $0,008^{*}$ \\
\hline $\mathrm{mMVG}(\mathrm{mmHg})$ & $15(4-20)$ & $13,5(8-27)$ & $12(8-20)$ & 0,631 \\
\hline LAd (mm) & $47 \pm 5,22$ & $49,5 \pm 6,33$ & $54,84 \pm 10,7$ & 0,051 \\
\hline $\mathrm{LAVi}\left(\mathrm{mL} / \mathrm{m}^{2}\right)$ & $100,17 \pm 60,31$ & $86,85 \pm 29,91$ & $104,53 \pm 42,08$ & 0,514 \\
\hline \multirow[t]{2}{*}{ sICAM-1 (ng/mL) } & 284,74 & 346,86 & 395,93 & 0,280 \\
\hline & $(218,79-321)$ & $(125,68-698,12)$ & $(171,44-1021,53)$ & \\
\hline \multirow[t]{2}{*}{ sVCAM-1 (ng/mL) } & 729,01 & 1066,00 & 1158,00 & $0,016^{*}$ \\
\hline & $(543,93-967,80)$ & $(581,36-2470,60)$ & $(668,66-2498,30)$ & \\
\hline
\end{tabular}

$\mathrm{AF}=$ atrial fibrillation $; \mathrm{MVA}=$ mitral valve area $; \mathrm{mMVG}=$ mean mitral valve gradient, $\mathrm{LAd}=$ left atrial dimension $; \mathrm{LAVi}=$ left atrial volume index ${ }^{*} \mathrm{p}<0,05$ 
Jurnal Kardiologi Indonesia

Tabel 3. Analisis multivariat terhadap gradasis trombosis atrium kiri

\begin{tabular}{|c|c|c|c|c|c|}
\hline $\begin{array}{l}\text { Gradasi } \\
\text { Trombosis }\end{array}$ & Variabel & B & Rasio odds & Indeks kepercayaan 95\% & $\mathrm{p}$ \\
\hline \multirow[t]{5}{*}{ Non-trombus dengan LASEC tebal } & sVCAM-1 & 0,006 & 1,006 & $0,999-1,014$ & 0,100 \\
\hline & Laki-laki & $-4,589$ & 0,010 & $<0,001-2,118$ & 0,092 \\
\hline & $\mathrm{AF}$ & 0,229 & 1,257 & $0,040-35,519$ & 0,897 \\
\hline & MVA & $-7,506$ & 0,001 & $<0,001-15,462$ & 0,151 \\
\hline & LAd & 0,135 & 1,145 & $0,855-1,532$ & 0,364 \\
\hline \multirow[t]{5}{*}{ Trombus } & sVCAM-1 & 0,006 & 1,006 & $0,998-1,014$ & 0,145 \\
\hline & Laki-laki & $-1,865$ & 0,155 & $0,002-15,062$ & 0,425 \\
\hline & $\mathrm{AF}$ & 4,240 & 69,379 & $1,293-3723,035$ & $0,037^{*}$ \\
\hline & MVA & $-12,260$ & $<0,001$ & $<0,001-0,339$ & $0,032^{*}$ \\
\hline & LAd & 0,109 & 1,116 & $0,831-1,497$ & 0,467 \\
\hline
\end{tabular}

Kategori referensi: non-trombus tanpa LASEC tebal

${ }^{*} \mathrm{p}<0,05$

perbedaan rerata ini tidak signifikan $(\mathrm{p}=0,280)$. Kadar rerata sVCAM-1 juga didapatkan pada kelompok trombus yang diikuti oleh kelompok non-trombus dengan LASEC tebal dan kelompok non-trombus tanpa LASEC tebal. Terdapat perbedaan signifikan kadar sVCAM-1 diantara kelompok-kelompok tersebut $(\mathrm{p}=0,016)$. Analisis bivariat terhadap gradasi trombosis atrium kiri ditampilkan pada Tabel 2 .

Pada analisis multivariat, kadar sVCAM-1 tidak signifikan mempengaruhi gradasi trombosis di atrium kiri. Pada analisis dengan kelompok non-trombus tanpa LASEC tebal sebagai referensi, MVA dan irama jantung berupa AF tampak mempengaruhi secara signifikan terhadap kejadian trombus sebagaimana diperlihatkan pada analisis kelompok trombus. Analisis multivariat ditampilkan pada Tabel 3.

Kemudian dilakukan analisis pada sub kelompok AF untuk mengetahui adakah hubungan kadar sICAM-1 dan sVCAM-1 terhadap ada tidaknya trombus di atrium kiri. Subyek penelitian dengan irama EKG berupa AF berjumlah 26 orang. Analisis terhadap kelompok trombus dan non-trombus menunjukkan tidak adanya perbedaan signifikan dari kadar sICAM-1 $(\mathrm{p}=0,912)$ dan sVCAM-1 ( $\mathrm{p}=0,617)$.

Penilaian gradasi trombosis atrium kiri pada penelitian ini menunjukkan derajat kesesuaian intraobsever dan interobserver yang baik. Nilai Cronbach's alpha untuk kesesuaian intraobsever dan interobserver masing masing sebesar 0,9734 dan 0,9844. Intraclass Coefficient Correlation untuk kesesuaian intraobsever dan interobserver masing masing sebesar $0,9724(0,9473$ - 0,9855) dan 0,9844 $(0,9734-0,9913)$.

\section{Pembahasan}

Pada penelitian ini didapatkan tidak ada perbedaan kadar sICAM-1 diantara kelompok menurut gradasi trombosis atrium kanan, sedangkan kadar sVCAM-1 didapatkan berbeda diantara kelompok menurut gradasi trombosis tersebut. Kadar rerata sVCAM-1 meningkat sesuai urutan sebagai berikut: kelompok non-trombus tanpa LASEC tebal, kelompok nontrombus dengan LASEC tebal, dan kelompok trombus. Namun pada analisis multivariat dengan kelompok non-trombus tanpa LASEC tebal sebagai pembanding, didapatkan bahwa AF dan MVA yang meningkatkan trombosis. Hal ini dikonfirmasi juga dengan melakukan analisis pada sub kelompok AF yang mendapatkan tidak adanya perbedaan kadar sICAM-1 dan sVCAM-1 pada kelompok dengan trombus dan tanpa trombus.

Penelitian yang menghubungkan mediator inflamasi khususnya molekul adhesi dengan SM belum banyak dilakukan. Chen $\mathrm{dkk}^{7}$ dan Yetkin $\mathrm{dkk}^{11}$ telah melakukan penelitian tentang kadar sICAM-1 dan sVCAM-1 pada $S M$, namun tidak dikaitkan kadar mediatormediator inflamasi tersebut dengan trombosis pada SM. Penelitian oleh Yetkin dkk mendapatkan bahwa kadar sICAM-1 dan sVCAM-1 meningkat pada kelompok SM dibandingkan dengan kelompok kontrol normal. Tidak disebutkan data mengenai penilaian ekokardiografi transesofageal untuk menilai trombus pada penelitian tersebut. Sedangkan Chen dkk mendapatkan bahwa kadar sVCAM-1 meningkat pada kelompok pasien SM reumatik (tanpa adanya regurgitasi mitral signifikan ataupun trombus) 
Sahara E dkk: Hubungan kadar sICAM-I dan sVCAM-I dengan gradasi trombosis atrium kiri pada stenosis mitral

dibandingkan dengan kelompok kontrol normal dan kelompok AF. Kadar sICAM-1 tidak berbeda bermakna diantara kelompok-kelompok tersebut. Tidak adanya trombus di atrium kiri atau apendiks atrium kiri telah dikonfirmasi dengan pemeriksaan TEE pada penelitian tersebut. Pada penelitian ini didapatkan perbedaan signifikan kadar sVCAM-1 diantara kelompok menurut gradasi trombosis namun tidak demikian dengan kadar sICAM-1. Hal ini dapat disebabkan oleh VCAM-1 yang lebih spesifik diekspresikan oleh endotel permukaan dibandingkan ICAM-1.

Beberapa penelitian telah mengaitkan VCAM-1 dengan kejadian trombosis. Pada mata tikus yang dipaparkan dengan 2-butoksietanol, fungsi VCAM1 yang dievaluasi secara histologis dan ekspresi imunohistokimia tampak berperan dalam proses trombosis pada mata dengan memfasilitasi adhesi eritrosit pada endotelium. ${ }^{9}$ Konsentrasi sVCAM-1 juga didapatkan meningkat pada pasien DVT dibandingkan dengan kontrol normal. ${ }^{12}$

Kaplanski $\mathrm{dkk}^{8}$ melakukan penelitian mengenai sICAM-1 dan sVCAM-1 yang dihubungkan dengan derajat keparahan trombosis pada pasien sindrom antifosfolipid (APS) primer dan APS terkait systemic lupus erithematosus (SLE-APS). Pada penelitian tersebut digunakan teknik ELISA dengan peralatan yang sejenis dengan penelitian ini. Pada APS dengan trombosis berat (minimal 3 kali riwayat kejadian trombosis) didapatkan kadar sVCAM-1 sebesar $1270 \pm 105$ ng/mL sedangkan pada APS tanpa trombosis berat didapatkan kadar sVCAM-1 sebesar $683 \pm 59 \mathrm{ng} / \mathrm{mL}$, dimana didapatkan perbedaan signifikan antara 2 kelompok tersebut. Pada APS primer, tidak didapatkan perbedaan kadar sICAM-1 antara kelompok dengan trombosis berat dan kelompok tanpa trombosis berat $(283 \pm 36 \mathrm{ng} / \mathrm{mL}$ vs $254 \pm 17 \mathrm{ng} /$ $\mathrm{mL}$ ). Hal serupa juga didapatkan pada kelompok SLEAPS dalam perbandingan kadar sICAM-1 dan sVCAM-1 antara kelompok dengan trombosis berat dan kelompok tanpa trombosis berat. Dari hasil tersebut, kadar sVCAM-1 didapatkan berbeda secara signifikan pada kelompok menurut derajat keparahan trombosis.

APS merupakan suatu kelainan yang memiliki karakteristik berupa peningkatan persisten antibodi antifosfolipid sehingga bermanifestasi sebagai trombosis arteri dan vena berulang. Autoantibodi berupa antibodi antifosfolipid ini menyebabkan status hiperkoagubilitas dengan beberapa cara, yaitu: memproduksi antibodi langsung terhadap faktor koagulasi dan faktor antifibrinolitik; mengaktifkan trombosit, leukosit dan endotel sehingga mengekspresikan CAM dan TF; serta mengoksidasi low-density lipoprotein. ${ }^{13,}{ }^{14}$ Faktor imunologi dan inflamasi tampak dominan dalam patogenesis trombosis pada APS. Berbeda dari APS, SM memiliki kelainan hemodinamik pada atrium kiri disamping inflamasi kronis akibat penyakit jantung reumatik yang umumnya mendasari terjadinya SM. Peningkatan kadar sICAM-1 dan sVCAM-1 pada pasien SM telah diungkapkan oleh beberapa peneliti yang telah disebutkan sebelumnya, namun bagaimana hubungan mediator inflamasi tersebut dengan trombosis pada SM belum diketahui sebelumnya. Pada penelitian ini didapatkan bahwa komponen inflamasi tampaknya tidak mempengaruhi beratnya trombosis atrium kiri.

Pada penelitian ini, faktor hemodinamik khususnya AF dan ukuran MVA lebih mempengaruhi trombosis pada penyakit SM. Pada penelitian-penelitian sebelumnya, proporsi pasien dengan trombus atrium kiri pada SM derajat berat yang disertai AF didapatkan sebesar 33 - 38\%. SM derajat berat dengan AF meningkatkan risiko trombosis 18 kali lipat. ${ }^{15,16}$

\section{Keterbatasan penelitian}

Keterbatasan penelitian ini adalah sulitnya memperoleh subyek penelitian karena pasien SM dengan derajat sedang sampai berat yang diikutsertakan dipilih yang tidak memiliki kelainan regurgitasi mitral yang signifikan. Adanya regurgitasi mitral yang signifikan menurunkan angka kejadian terbentuknya trombus dan LASEC pada atrium kiri. Dalam pengamatan didapatkan proporsi kelompok non-trombus tanpa LASEC tebal didapatkan kecil sehingga jumlah subyek kelompok non-trombus tanpa LASEC tebal lebih sedikit dibandingkan kelompok lainnya.

\section{Kesimpulan}

Tidak terdapat perbedaan kadar sICAM-1 pada kelompok menurut gradasi trombosis atrium kiri pada SM. Terdapat perbedaan kadar sVCAM-1 pada kelompok menurut gradasi trombosis atrium kiri pada SM, namun pengaruh sVCAM-1 terhadap gradasi trombosis atrium kiri dipengaruhi oleh AF dan MVA.

\section{Daftar Pustaka}

1. Padmavati S. Rheumatic fever and rheumatic heart disease in India at the turn of the century. Indian Heart J. 2001;53(1):35-7. 
2. Chandrashekhar Y, Westaby S, Narula J. Mitral stenosis. Lancet. 2009;374(9697):1271-83.

3. Peverill RE, Harper RW, Gelman J, Gan TE, Harris G, Smolich JJ. Determinants of increased regional left atrial coagulation activity in patients with mitral stenosis. Circulation. 1996;94(3):331-9.

4. Yamamoto K, Ikeda U, Seino Y, Mito H, Fujikawa H, Sekiguchi $\mathrm{H}$, et al. Coagulation activity is increased in the left atrium of patients with mitral stenosis. J Am Coll Cardiol. 1995;25(1):10712.

5. Goldsmith I, Kumar P, Carter P, Blann AD, Patel RL, Lip GY. Atrial endocardial changes in mitral valve disease: a scanning electron microscopy study. Am Heart J. 2000;140(5):777-84.

6. Kaski JC, Arrebola-Moreno AL. Inflammation and thrombosis in atrial fibrillation. Rev Esp Cardiol. 2011;64(7):551-3.

7. Chen MC, Chang HW, Juang SS, Yip HK, Wu CJ, Yu TH, et al. Percutaneous transluminal mitral valvuloplasty reduces circulating vascular cell adhesion molecule-1 in rheumatic mitral stenosis. Chest. 2004;125(4):1213-7.

8. Kaplanski G, Cacoub P, Farnarier C, Marin V, Gregoire R, Gatel A, et al. Increased soluble vascular cell adhesion molecule 1 concentrations in patients with primary or systemic lupus erythematosus-related antiphospholipid syndrome: correlations with the severity of thrombosis. Arthritis Rheum. 2000;43(1):5564.

9. Nyska A, Moomaw CR, Ezov N, Shabat S, Levin-Harrus T, Nyska M, et al. Ocular expression of vascular cell adhesion molecule (VCAM-1) in 2-butoxyethanol-induced hemolysis and thrombosis in female rats. Exp Toxicol Pathol. 2003;55(4):231-
6.

10. Isogai N, Tanaka H, Asamura S. Thrombosis and altered expression of intercellular adhesion molecule-1 (ICAM-1) after avulsion injury in rat vessels. J Hand Surg Br. 2004;29(3):230-4.

11. Yetkin E, Erbay AR, Ileri M, Turhan H, Balci M, Cehreli S, et al. Levels of circulating adhesion molecules in rheumatic mitral stenosis. Am J Cardiol. 2001;88(10):1209-11.

12. Gonzalez-Ordonez AJ, Fernandez-Carreira JM, Fernandez-Alvarez CR, Venta Obaya R, Macias-Robles MD, Gonzalez-Franco $\mathrm{A}$, et al. The concentrations of soluble vascular cell adhesion molecule- 1 and lipids are independently associated with venous thromboembolism. Haematologica. 2003;88(9):1035-43.

13. Salmon JE, Girardi G, Lockshin MD. The antiphospholipid syndrome as a disorder initiated by inflammation: implications for the therapy of pregnant patients. Nat Clin Pract Rheumatol. 2007;3(3):140-7.

14. Pierangeli SS, Espinola RG, Liu X, Harris EN. Thrombogenic effects of antiphospholipid antibodies are mediated by intercellular cell adhesion molecule-1, vascular cell adhesion molecule-1, and P-selectin. Circ Res. 2001;88(2):245-50.

15. Goswami KC, Yadav R, Rao MB, Bahl VK, Talwar KK, Manchanda SC. Clinical and echocardiographic predictors of left atrial clot and spontaneous echo contrast in patients with severe rheumatic mitral stenosis: a prospective study in 200 patients by transesophageal echocardiography. Int J Cardiol. 2000;73(3):273-9.

16. Farman MT, Sial JA, Khan N, Rahu QA, Tasneem H, Ishaq M. Severe mitral stenosis with atrial fibrillation--a harbinger of thromboembolism. J Pak Med Assoc. 2010;60(6):439-43. 